\title{
Indium sulfide thin films as window layer in chemically deposited solar cells
}

\author{
S. Lugo-Loredo a,1, Y. Peña-Méndez ${ }^{\text {a,*,1 }}{ }^{\text {, }}$ M. Calixto-Rodriguez ${ }^{\text {b }}$, S. Messina-Fernández ${ }^{\text {c }}$, A. Alvarez-Gallegos ${ }^{\text {d }}$, \\ A. Vázquez-Dimas ${ }^{\mathrm{a}, 1}, \mathrm{~T}$. Hernández-García ${ }^{\mathrm{a}, 1}$ \\ a Universidad Autónoma de Nuevo León, UANL, Fac. de Ciencias Químicas, Av. Universidad S/N Ciudad Universitaria San Nicolás de Los Garza Nuevo León, C.P. 66451, Mexico \\ b Universidad Tecnológica Emiliano Zapata del Estado de Morelos, Av. Universidad Tecnológica No. 1, C.P. 62760 Emiliano Zapata, Morelos, Mexico \\ " Universidad Autónoma de Nayarit, Ciudad de la Cultura "Amado Nervo" S/N, C.P. 63190 Tepic, Nayarit, Mexico \\ d Universidad Autónoma del Estado de Morelos, Centro de Investigación en Ingeniería y Ciencias Aplicadas, Av. Universidad 1001, C.P. 62209, Cuernavaca Morelos, Mexico
}

\section{A R T I C L E I N F O}

\section{Article history:}

Received 30 January 2013

Received in revised form 16 September 2013

Accepted 18 October 2013

Available online 29 October 2013

\section{Keywords:}

Indium sulfide

Chemical bath deposition

Thin films

Solar cells

\begin{abstract}
A B S T R A C T
Indium sulfide $\left(\mathrm{In}_{2} \mathrm{~S}_{3}\right)$ thin films have been synthesized by chemical bath deposition technique onto glass substrates using $\mathrm{In}\left(\mathrm{NO}_{3}\right)_{3}$ as indium precursor and thioacetamide as sulfur source. X-ray diffraction studies have shown that the crystalline state of the as-prepared and the annealed films is $\beta-\operatorname{In}_{2} \mathrm{~S}_{3}$. Optical band gap values between 2.27 and $2.41 \mathrm{eV}$ were obtained for these films. The $\operatorname{In}_{2} \mathrm{~S}_{3}$ thin films are photosensitive with an electrical conductivity value in the range of $10^{-3}-10^{-7}(\Omega \mathrm{cm})^{-1}$, depending on the film preparation conditions. We have demonstrated that the $\mathrm{In}_{2} \mathrm{~S}_{3}$ thin films obtained in this work are suitable candidates to be used as window layer in thin film solar cells. These films were integrated in $\mathrm{SnO}_{2}: \mathrm{F} / \mathrm{In}_{2} \mathrm{~S}_{3} / \mathrm{Sb}_{2} \mathrm{~S}_{3} / \mathrm{PbS} / \mathrm{C}-\mathrm{Ag}$ solar cell structures, which showed an open circuit voltage of $630 \mathrm{mV}$ and a short circuit current density of $0.6 \mathrm{~mA} / \mathrm{cm}^{2}$.
\end{abstract}

(c) 2013 Elsevier B.V. All rights reserved.

\section{Introduction}

Many efforts have been done by several research groups in order to replace CdS buffer layer in thin film solar cells by using an alternative semiconductor with a wide band gap, mainly due to environmental reasons. Indium sulfide has been recognized as an alternative material due to their stability, transparency, photoconductive nature and because of the energy band gap that can be varied between 2 and $2.75 \mathrm{eV}$ depending on its composition [1-6]. Several crystalline phases have been reported for the $\operatorname{In}_{2} S_{3}$ thin films $(\alpha, \beta$ and $\gamma)$ and it has been found that the most stable phase at room temperature is the $\beta$-tetragonal [6]. Polycrystalline $\mathrm{In}_{2} \mathrm{~S}_{3}$ thin films have been used as window layer in $\operatorname{In}_{2} \mathrm{~S}_{3} /$ CuInX $_{2}(\mathrm{X}=\mathrm{S}$ or $\mathrm{Se})$ solar cell structures [4].

Among the chemical methods used for the preparation of $\operatorname{In}_{2} S_{3}$ thin films are metal-organic chemical vapor deposition [7], atomic layer deposition [8], thermal evaporation technique [9], modulated flux deposition [10], spray pyrolysis [11], electrodeposition [12], and chemical bath deposition (CBD) [1,13]. CBD has been recognized as the simplest and most economical method to obtain semiconductor thin films. In this work we report the deposition of $\operatorname{In}_{2} \mathrm{~S}_{3}$ thin films using CBD and their application as window layers in thin film solar cells.

\footnotetext{
* Corresponding author at: Facultad de Ciencias Químicas-UANL, C.P. 66451, Mexico. Tel.: + 52 8183294000x6363; fax: + 528183765375

E-mail address: yolapm@gmail.com (Y. Peña-Méndez).

1 Tel.: +81 83294000x6363
}

\section{Experimental details}

\section{1. $\operatorname{In}_{2} \mathrm{~S}_{3}$ window layer}

The deposition of the indium sulfide thin films was done on Corning glass substrates $(2.5 \mathrm{~cm} \times 7.5 \mathrm{~cm} \times 0.1 \mathrm{~cm})$. The substrates were previously washed out with a soapy solution, then rinsed with distilled water and dried in flowing air. For depositing the indium sulfide thin films, an acidic chemical bath solution composed of $\operatorname{In}\left(\mathrm{NO}_{3}\right)_{3} 0.01 \mathrm{M}, \mathrm{CH}_{3} \mathrm{COOH}$ $2 \times 10^{-3} \mathrm{M}$ and $\mathrm{CH}_{3} \mathrm{CSNH}_{2} 0.16 \mathrm{M}$ at a pH of 2.60 was used. Normally, the addition of $\mathrm{CH}_{3} \mathrm{COOH}$ is used to reduce the $\mathrm{pH}$ value of the bath and to promote the hydrolysis of thioacetamide [14]. The substrates were vertically placed into the beaker. The chemical reaction was carried out at $35{ }^{\circ} \mathrm{C}$, and the deposition time was varied from 12 to $39 \mathrm{~h}$.

\subsection{Thermal treatments}

The indium sulfide thin films were annealed in a Thermolyne 21100 tubular furnace at temperatures of 350 and $400{ }^{\circ} \mathrm{C}$ for $1 \mathrm{~h}$ under a stream of $\mathrm{N}_{2}$ flowing through the tube.

\subsection{Solar cell structures}

The structure of the proposed solar cell is similar to that reported previously in Ref. [15], however, in the present work we have substituted the CdS layer by our $\operatorname{In}_{2} \mathrm{~S}_{3}$ window layer. The $\mathrm{Sb}_{2} \mathrm{~S}_{3}$ thin film 
(200 nm) was deposited onto the $\operatorname{In}_{2} S_{3}$ thin film previously deposited on $3 \mathrm{~mm}$ glass substrates coated with $\mathrm{SnO}_{2}: \mathrm{F}$, a transparent conductive oxide (TEC-15 by Pilkington). The $\mathrm{SnO}_{2}: \mathrm{F} / \mathrm{In}_{2} \mathrm{~S}_{3} / \mathrm{Sb}_{2} \mathrm{~S}_{3}$ structure was subsequently heated in $\mathrm{N}_{2}$ flow at $350{ }^{\circ} \mathrm{C}$ for $0.5 \mathrm{~h}$. After that a PbS thin film (200 nm) was deposited as $\mathrm{p}^{+}$absorber, as suggested in Ref. [16]. Then graphite paint was applied on the PbS film and finally, a silver paint electrode was applied to be used as p-side contact.

\section{Characterization of the $\operatorname{In}_{2} S_{3}$ thin films}

X-ray diffraction (XRD) analysis was performed on a Rigaku D-Max 2000 X-ray diffractometer using $\mathrm{Cu}-\mathrm{K}_{\alpha}$ radiation $(\lambda=1.5406 \AA)$ in the grazing incidence mode at $\Omega=1.5^{\circ}$. The optical transmittance response was measured in a Shimadzu $1800 \mathrm{UV}$-Vis spectrophotometer in the wavelength range of $250-1100 \mathrm{~nm}$ using air as reference. Photocurrent response of the films was obtained using a tungsten-halogen lamp and a Keithley 6487 multimeter. Morphology of the films was studied by atomic force microscopy (AFM) using an AA3000 atomic force microscope from Angstrom Advanced, the measurements were performed in the contact mode. Field emission scanning electron microscopy (FE-SEM) images of the $\operatorname{In}_{2} \mathrm{~S}_{3}$ thin films were obtained using a FE-SEM JEOL JSM 6701F microscope, the operating voltage was $2-3 \mathrm{kV}$.

\section{Results and discussion}

It was found that the $\operatorname{In}_{2} \mathrm{~S}_{3}$ thin films chemically deposited for $12 \mathrm{~h}$ have a thickness of $85 \mathrm{~nm}$ and those deposited for 39 h have a thickness of $\sim 500 \mathrm{~nm}$.

\subsection{Structural properties of $\mathrm{In}_{2} \mathrm{~S}_{3}$ thin films}

Fig. 1 shows the XRD patterns of the $\operatorname{In}_{2} S_{3}$ thin films (500 nm) recorded at a grazing incidence angle of $1.5^{\circ}$ for the as-prepared and annealed samples at 350 and $400{ }^{\circ} \mathrm{C}$ for $1 \mathrm{~h}$ in $\mathrm{N}_{2}$. The XRD patterns match well with that of the standard pattern of the tetragonal phase $\beta-\mathrm{In}_{2} \mathrm{~S}_{3}$ (PDF 25-0390). The as-prepared films showed a polycrystalline nature, and after the annealing treatment at $400{ }^{\circ} \mathrm{C}$ a little improvement of the films crystallinity was observed. The standard pattern for $\beta-\operatorname{In}_{2} \mathrm{~S}_{3}$ (PDF 25-0390) is given in Fig. 1 for comparison.

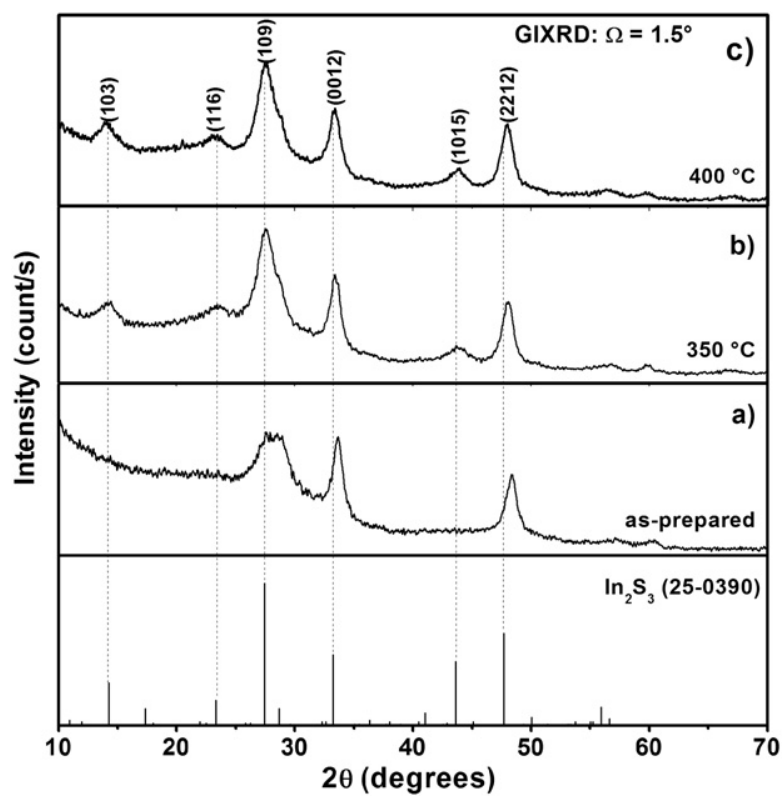

Fig. 1.X-ray diffraction patterns of $\operatorname{In}_{2} \mathrm{~S}_{3}$ thin films with $39 \mathrm{~h}$ of deposition, a) as-prepared, b) annealed at $350{ }^{\circ} \mathrm{C}$, and c) annealed at $400{ }^{\circ} \mathrm{C}$ in $\mathrm{N}_{2}$ atmosphere for $1 \mathrm{~h}$.

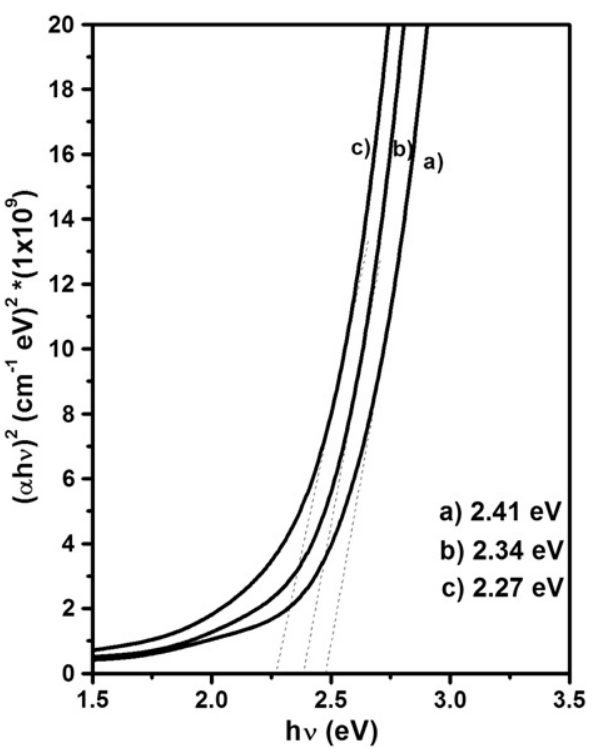

Fig. 2. Energy band gap values for the $\operatorname{In}_{2} \mathrm{~S}_{3}$ thin films with $39 \mathrm{~h}$ of deposition, a) asprepared, b) annealed at $350{ }^{\circ} \mathrm{C}$, and c) annealed at $400{ }^{\circ} \mathrm{C}$ in $\mathrm{N}_{2}$ for $1 \mathrm{~h}$.

\subsection{Optical properties of $\operatorname{In}_{2} S_{3}$ thin films}

The band gap $\left(E_{g}\right)$ values were calculated from the optical transmittance spectra results considering that the absorption coefficient $(\alpha)$ is a function of the photon energy $(h v)$ using the following equation [17]:

$\alpha=(1 / d) \ln (100 / \% T)$

where $d$ is the thickness of the film and $T$ the optical transmittance.

The $E_{g}$ value was determined by extrapolating the linear part of the plot $(\alpha h v)^{2}$ vs. (hv) in the abscissa (axis $\mathrm{x}$ ), which indicates a direct optical transition. The $(\alpha h v)^{2}$ vs. (hv) plots are shown in Fig. 2 for asprepared and annealed $\beta$ - $\mathrm{In}_{2} \mathrm{~S}_{3}$ films $(500 \mathrm{~nm})$. For these $\beta$ - $\mathrm{In}_{2} \mathrm{~S}_{3}$ samples the calculated band gap values were $2.41,2.34$ and $2.27 \mathrm{eV}$ for the as-prepared, annealed at $350{ }^{\circ} \mathrm{C}$, and $400{ }^{\circ} \mathrm{C}$, respectively. These values are in agreement with those reported in the literature for this material [1]. We observed a decrease in the $E_{g}$ value when the annealing temperature increases, which can be attributed to an increase in grain size.

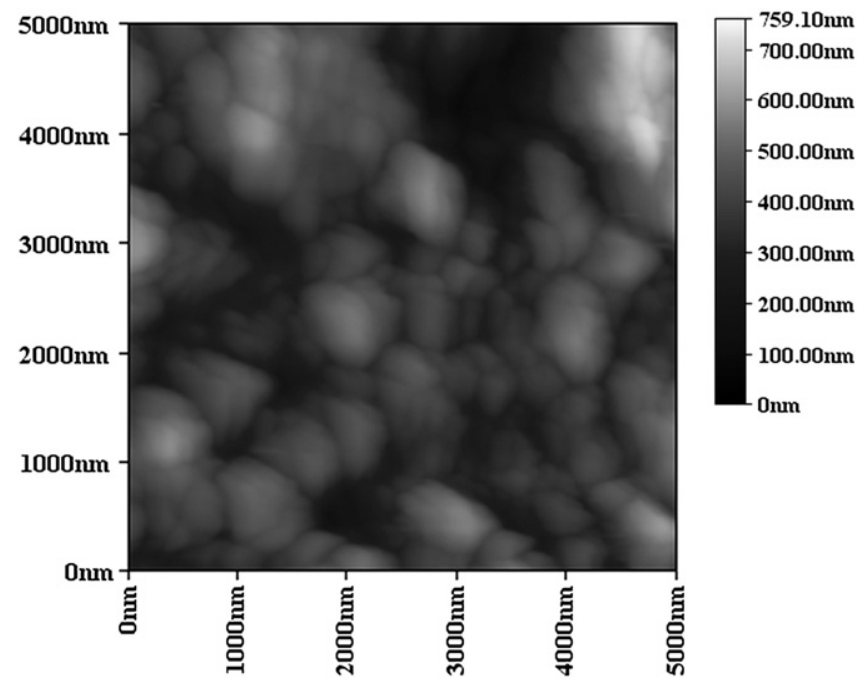

Fig. 3. AFM image of the $\beta-\operatorname{In}_{2} S_{3}$ thin film with $39 \mathrm{~h}$ of deposition, after thermal treatment at $400{ }^{\circ} \mathrm{C}$ in $\mathrm{N}_{2}$ atmosphere for $1 \mathrm{~h}$. 


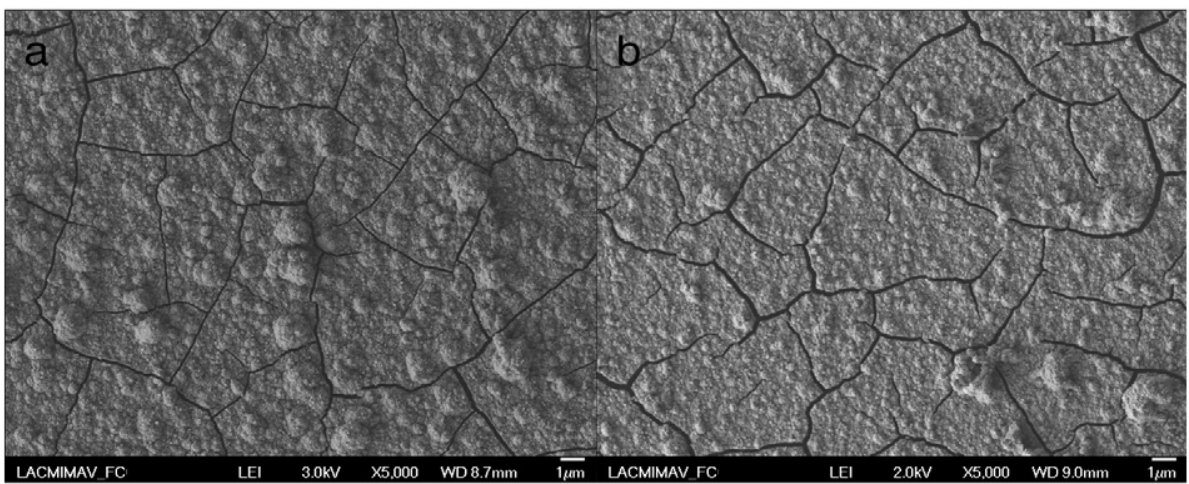

Fig. 4. FE-SEM images of $\beta-\operatorname{In}_{2} S_{3}$ thin films with $39 \mathrm{~h}$ of deposition, a) before and b) after thermal treatment at $350{ }^{\circ} \mathrm{C}$ in $\mathrm{N}_{2}$ atmosphere for $1 \mathrm{~h}$.

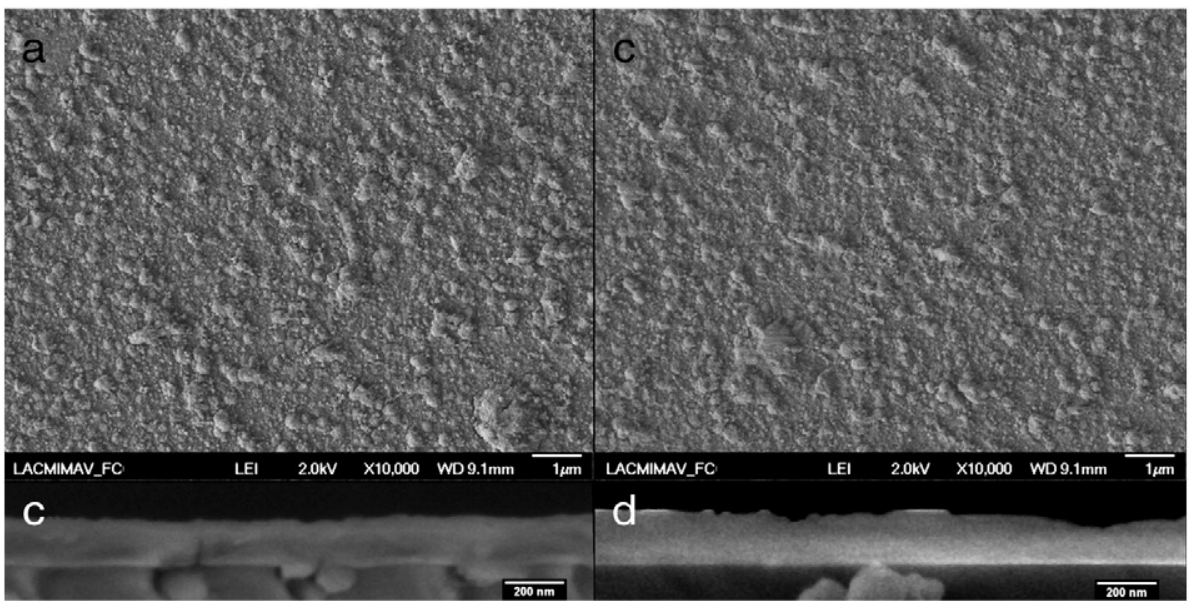

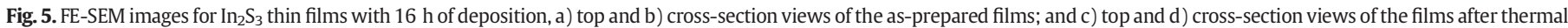
treatment at $350{ }^{\circ} \mathrm{C}$ in $\mathrm{N}_{2}$ atmosphere for $1 \mathrm{~h}$.

\subsection{Morphological properties of $I_{2} S_{3}$ thin films}

Fig. 3 shows a 2D AFM image for the $\beta-\mathrm{In}_{2} \mathrm{~S}_{3}$ thin film with an average thickness of $500 \mathrm{~nm}$ after the annealing treatment at $400{ }^{\circ} \mathrm{C}$ in $\mathrm{N}_{2}$. The morphology of the film surface shows grain sizes from $<100 \mathrm{~nm}$ up to $800 \mathrm{~nm}$. On the other hand, FE-SEM images of $\ln _{2} S_{3}$ thin films $(500 \mathrm{~nm})$ revealed a cracked surface for the as-prepared and annealed samples at $350{ }^{\circ} \mathrm{C}$ (see Fig. 4).

Fig. $5 \mathrm{a}$ and $\mathrm{b}$ shows a representative FE-SEM image of the top and cross-section views of the as-prepared $\mathrm{In}_{2} \mathrm{~S}_{3}$ films $(165 \mathrm{~nm})$. Fig. $5 \mathrm{c}$ and d corresponds to the $\mathrm{In}_{2} \mathrm{~S}_{3}$ thin film annealed at $350{ }^{\circ} \mathrm{C}$ for $1 \mathrm{~h}$ in $\mathrm{N}_{2}$ atmosphere. According to this figure, after the annealing process a slight difference in thickness (157 nm) is observed in the film, which can be due to shrinking. In this case, the film surface is homogeneous and crack-free. According to these results, the $157 \mathrm{~nm} \mathrm{In}_{2} \mathrm{~S}_{3}$ film shows suitable characteristics to be employed as window layer in thin-film solar cells.

\subsection{Electrical properties of $\operatorname{In}_{2} S_{3}$ thin films}

The photocurrent response of as-prepared and annealed at 350 and $400{ }^{\circ} \mathrm{C} \beta-\mathrm{In}_{2} \mathrm{~S}_{3}$ thin films (500 nm) are shown in Fig. 6. Inset in Fig. 6 shows the photocurrent response of $\operatorname{In}_{2} \mathrm{~S}_{3}$ film $(150 \mathrm{~nm})$ after the annealing process at $400{ }^{\circ} \mathrm{C}$ for $1 \mathrm{~h}$ in $\mathrm{N}_{2}$ atmosphere. The electrical conductivities of the $\beta-\mathrm{In}_{2} S_{3}$ thin films (500 nm) were $4.34 \times 10^{-8}(\Omega \mathrm{cm})^{-1}$ and $2.05 \times 10^{-7}(\Omega \mathrm{cm})^{-1}$ after annealing at $350^{\circ} \mathrm{C}$ and $400{ }^{\circ} \mathrm{C}$, respectively. In the case of $\operatorname{In}_{2} S_{3}$ thin films with a thickness of $150 \mathrm{~nm}$, an electrical conductivity value of $2.8 \times 10^{-3}(\Omega \mathrm{cm})^{-1}$ was obtained after performing the thermal annealing at $400{ }^{\circ} \mathrm{C}$. This is a very important result since there are no electrical conductivity values reported in the literature for $\operatorname{In}_{2} \mathrm{~S}_{3}$ thin films obtained by CBD.
4.5. $\mathrm{J}-\mathrm{V}$ characteristics of the $\mathrm{SnO}_{2}: \mathrm{F} / \mathrm{In}_{2} \mathrm{~S}_{3} / \mathrm{Sb}_{2} \mathrm{~S}_{3} / \mathrm{PbS} / \mathrm{C}-\mathrm{Ag}$ photovoltaic structure

The current density (J) vs. voltage (V) characteristics of three solar cell structures are given in Fig. 7. The fabricated solar cells have the $\mathrm{SnO}_{2}: \mathrm{F} / \mathrm{In}_{2} \mathrm{~S}_{3} / \mathrm{Sb}_{2} \mathrm{~S}_{3}(200 \mathrm{~nm}) / \mathrm{PbS}(200 \mathrm{~nm}) / \mathrm{C}-\mathrm{Ag}$ structure, formed using an as-prepared $\operatorname{In}_{2} S_{3}$ (Fig. 7a and b) and a thermally treated $\mathrm{In}_{2} \mathrm{~S}_{3}$ thin-film at $350{ }^{\circ} \mathrm{C}$ in $\mathrm{N}_{2}$ flow for $1 \mathrm{~h}$ (Fig. $7 \mathrm{c}$ ). In the solar cell

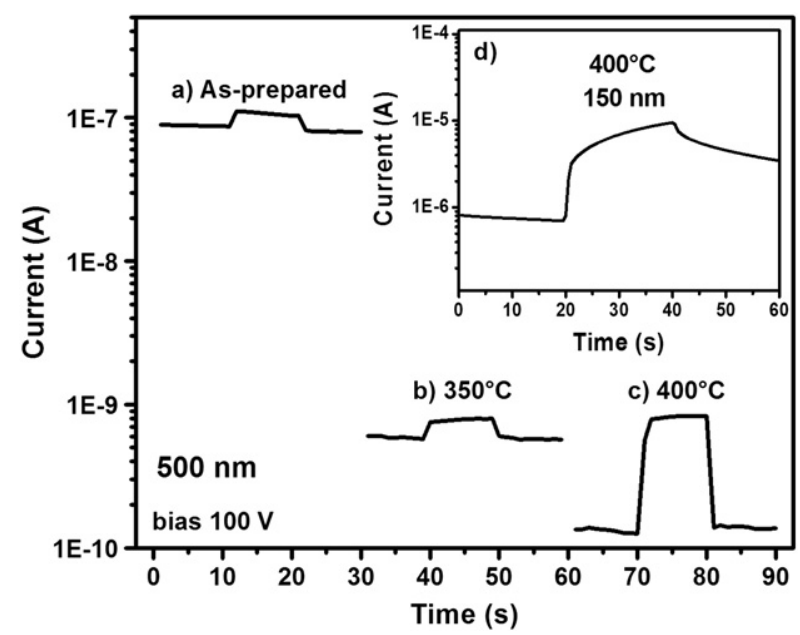

Fig. 6. Photoresponse of the $\beta-\operatorname{In}_{2} S_{3}$ thin films with $39 \mathrm{~h}$ of deposition, a) as-prepared, b) annealed at $350{ }^{\circ} \mathrm{C}$ in $\mathrm{N}_{2}$, and c) annealed at $400{ }^{\circ} \mathrm{C}$ in $\mathrm{N}_{2}$. Inset d): photoresponse of the $\beta$ - $\mathrm{In}_{2} \mathrm{~S}_{3}$ thin film with $16 \mathrm{~h}$ of deposition after annealing at $400{ }^{\circ} \mathrm{C}$. 


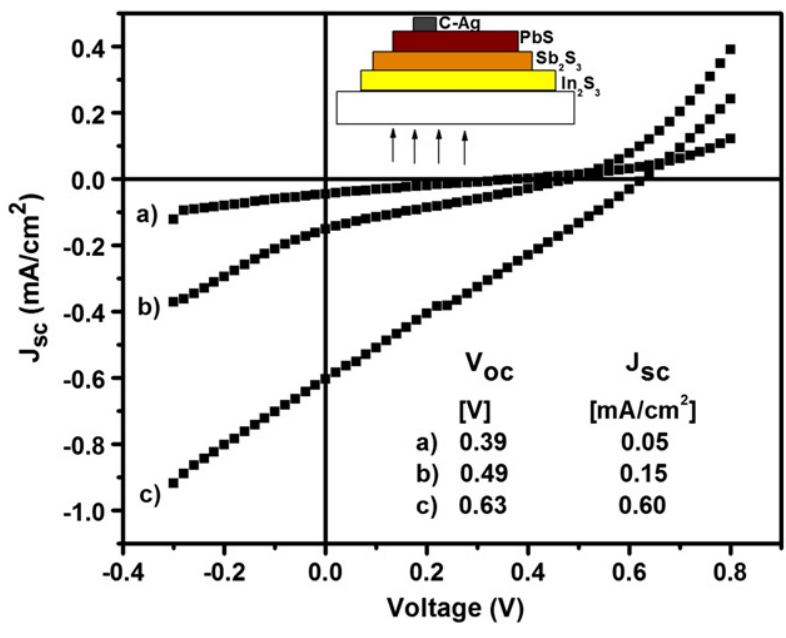

Fig. 7. J-V characteristics of the $\mathrm{SnO}_{2}: \mathrm{F} / \mathrm{In}_{2} \mathrm{~S}_{3} / \mathrm{Sb}_{2} \mathrm{~S}_{3} / \mathrm{PbS} / \mathrm{C}-\mathrm{Ag}$ photovoltaic structures using a) an as-prepared $\operatorname{In}_{2} \mathrm{~S}_{3}$ layer with a thickness of $200 \mathrm{~nm}$; b) an as-prepared $\operatorname{In}_{2} \mathrm{~S}_{3}$ layer with a thickness of $165 \mathrm{~nm}$; and c) an $\mathrm{In}_{2} \mathrm{~S}_{3}$ layer with a thickness of $157 \mathrm{~nm}$ after thermal treatment at $350{ }^{\circ} \mathrm{C}$ in $\mathrm{N}_{2}$.

structures of Fig. 7a and b we used two as-prepared $\operatorname{In}_{2} \mathrm{~S}_{3}$ layers with thicknesses of 200 and $165 \mathrm{~nm}$, respectively. While in the solar cell structure of Fig. $7 \mathrm{c}$, we used an annealed $\operatorname{In}_{2} \mathrm{~S}_{3}$ thin film with a thickness of $157 \mathrm{~nm}$. The photovoltaic parameters obtained for these structures were: $V_{o c}=390 \mathrm{mV}$ and $J_{s c}=0.05 \mathrm{~mA} / \mathrm{cm}^{2}, V_{o c}=490 \mathrm{mV}$ and $J_{s c}=$ $0.15 \mathrm{~mA} / \mathrm{cm}^{2}$, and $V_{o c}=630 \mathrm{mV}$ and $J_{s c}=0.60 \mathrm{~mA} / \mathrm{cm}^{2}$ for Fig. $7 \mathrm{a}$, b and c, respectively. According to these results, a thinner $\operatorname{In}_{2} \mathrm{~S}_{3}$ layer produces better cell characteristics probably due to a wider band gap value.

The results showed in this work have demonstrated the feasibility of using $\operatorname{In}_{2} \mathrm{~S}_{3}$ films as window layers in cadmium free thin film solar cells. However, the deposition conditions could be further optimized in order to improve the optoelectronic properties of $\operatorname{In}_{2} \mathrm{~S}_{3}$ films, so that the J-V characteristics of the solar cells can also be improved.

\section{Conclusions}

It was shown that $\operatorname{In}_{2} \mathrm{~S}_{3}$ thin films can be obtained by using $\mathrm{CBD}$ technique. XRD analysis confirmed that the films have a polycrystalline nature showing the $\beta-I_{2} S_{3}$ phase in both cases, the as-prepared and thermally treated films. The calculated band gap values for the $\operatorname{In}_{2} \mathrm{~S}_{3}$ films are in the range of 2.27 to $2.41 \mathrm{eV}$, these values are in agreement with those reported in the literature for this material. The films are photosensitive with electrical conductivity values of $\sim 10^{-3}-10^{-7}(\Omega \mathrm{cm})^{-1}$, depending on the film preparation conditions. In this work, it has been shown that the $\operatorname{In}_{2} \mathrm{~S}_{3}$ thin films obtained by CBD have optoelectronic properties suitable to be used as window layers in thin film solar cells. The best $\mathrm{J}-\mathrm{V}$ results obtained for the $\mathrm{SnO}_{2}: \mathrm{F} / \mathrm{\beta}-\mathrm{In}_{2} \mathrm{~S}_{3} / \mathrm{Sb}_{2} \mathrm{~S}_{3} / \mathrm{PbS} / \mathrm{C}-\mathrm{Ag}$ structure were $V_{o c}=630 \mathrm{mV}$ and $J_{s c}=0.6 \mathrm{~mA} / \mathrm{cm}^{2}$, which corresponds to the $157 \mathrm{~nm} \operatorname{In}_{2} \mathrm{~S}_{3}$ thin film thermally treated at $350{ }^{\circ} \mathrm{C}$. The results obtained in this work, for the $\mathrm{Cd}$ free solar cell structures are promising, however further work must be done in order to improve the optoelectronic properties of the $\operatorname{In}_{2} \mathrm{~S}_{3}$ layers.

\section{Acknowledgments}

We are grateful to Maria Luisa Ramon from IER-UNAM for the XRD measurements (IER-UNAM) and Dr. David Avellaneda from FIMEUANL for the electrical characterization of the films.

\section{References}

[1] M.G. Sandoval-Paz, M. Sotelo-Lerma, J.J. Valenzuela-Jáuregui, M. Flores-Acosta, R. Ramírez-Bon, Thin Solid Films 472 (2005) 5.

[2] A.M. Abdel Haleem, M. Ichimura, Thin Solid Films 516 (2008) 7783.

[3] Matthew Zervos, Pola Papageorgiou, Andreas Othonos, J. Cryst. Growth 312 (2010) 656.

[4] Indra Puspitasari, T.P. Gujar, Kwang-Deog Jung, Oh-Shim Joo, J. Mater. Proc. Technol. 201 (2008) 775.

[5] R.S. Mane, C.D. Lokhande, Mater. Chem. Phys. 78 (2002) 15.

6] Yi Liu, Huayun Xu, Yitai Qian, Double-Source Approach to $\mathrm{In}_{2} \mathrm{~S}_{3}$ Single Crystallites and Their Electrochemical Properties, Growth \& Design, 6 (6) (2006) 1304.

[7] S. Spiering, L. Bürkert, D. Hariskos, M. Powalla, B. Dimmler, C. Giesen, M. Heuken, Thin Solid Films 517 (2009) 2328.

[8] N. Naghavi, R. Henriquez, V. Laptev, D. Lincot, Appl. Surf. Sci. 222 (2004) 65.

[9] A. Timoumi, H. Bouzouita, M. Kanzari, B. Rezig, Thin Solid Films 480-481 (2005) 124.

[10] C. Sanz, C. Guillén, M.T. Gutiérrez, Thin Solid Films 511-512 (2006) 121.

[11] T.T. John, C.S. Kartha, K.P. Vijayakumar, T. Abe, Y. Kashiwaba, Appl. Surf. Sci. 252 (2005) 1360.

[12] T. Todorov, J. Carda, P. Escribano, A. Grimm, J. Klaer, R. Klenk, Sol. Energy Mater. Sol. Cells 92 (2008) 1274.

[13] B. Yahmadi, N. Kamoun, R. Bennaceur, M. Mnari, M. Dachraoui, K. Abdelkrim, Thin Solid Films 473 (2005) 201.

[14] C.D. Lokhande, A. Ennaoui, P.S. Patil, M. Giersig, K. Diesner, M. Muller, H. Tributsch, Thin Solid Films 340 (1999) 18

[15] Sarah Messina, M.T.S. Nair, P.K. Nair, Thin Solid Films 517 (2009) 2503.

[16] Sarah Messina, M.T.S. Nair, P.K. Nair, J. Phys. D. Appl. Phys. 41 (2008) 095.

[17] Ran Zhai, Shu Bo Wang, Hai Yan Xu, Hao Wang, Hui Yan, Mater. Lett. 59 (2005) 1497. 